\title{
A New Historicist Approach to Kazuo Ishiguro's When We Were Orphans
}

\author{
Kazuo Ishiguro'nun Çocukluğumu Ararken adlı Romanına Yeni Tarihselci \\ Bir Yaklaşım \\ Duygu SERDAROĞLU*
}

\begin{abstract}
New Historicism, flourishing in the 1980s as a "new" contemporary literary approach, proposes new viewpoints to the understanding of history and challenges the conventional understanding of history by pointing out the private histories. New Historicism deals with the representations of history rather than the history itself since it believes that there is not one history but multiple histories. The purpose of this article is to analyze the representation of history in Kazuo Ishiguro's When We Were Orphans from the New Historicist viewpoint by focusing on the concepts of time, memory and narrative technique, hence to reveal how history is narrated in subjective multiple ways and how personal histories and public histories are intermingled.
\end{abstract}

Key Words: New Historicism, representation of history, historicity of texts, textuality of history, memory, Kazuo Ishiguro.

Öz

1980’li yılların ortasında “yeni” bir edebi teori/yaklaşım olarak ortaya çıkan Yeni Tarihselcilik kuramı tarih anlayışına yeni bakış açıları sunmaktadır ve öznel tarih anlayışlarına vurgu yaparak geleneksel tarih anlayışına meydan okumaktadır. Yeni Tarihselcilik akımı tek bir tarih olmadığına ve çoklu tarih anlayışına inandığı için tarihin kendisiyle değil tarih(ler)in nasıl temsil edildiği ile ilgilenmektedir. Bu makalenin amacı Kazuo Ishiguro'nun Çocukluğumu Ararken adlı romanına Yeni Tarihselcilik edebi teorisi/yaklaşımı çerçevesinde zaman, bellek ve anlatım tekniği kavramlarına değinerek tarih temsilini incelemek ve böylece tarihin çeşitli öznel temsilleri ile kişisel ve genel tarihin nasıl iç içe geçtiğini ortaya çıkartmaktır.

Anahtar Sözcükler: Yeni Tarihselcilik, tarih temsili, metnin tarihselleşmesi, tarihin metinselleşmesi, bellek, Kazuo Ishiguro.

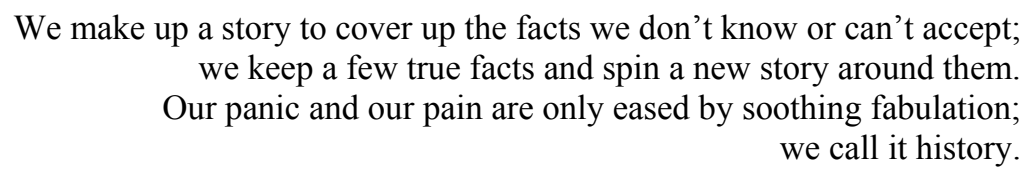

A History of the World in 10 and $1 / 2$ Chapters

New Historicism which has been defined as a "practice" rather than a doctrine emerged in the 1980s as a literary critical theory, and a new movement and it sees "works of literature as historical texts" because it questions past and what past represents by raising questions about the traditional representation, objectivity and universality of history (Doğan, 2006, p. 1). New Historicists believe that seeing a text/ a work of literature as a concrete separate entity free from the outside effects of the time is impossible since a text is a product of the social, political, and cultural elements of its time. Thus, for New Historicists, a text is not self-sufficient and complete in a way not to be interfered, but a product of the cultural, political and social events of the time in which it is written and as a result of this, it is open to multiple interpretations and it is also very difficult to talk about one ultimate interpretation that is the same and true for everyone and every time. Its reading, too, is problematic since each new reading is done under

\footnotetext{
*Dr., TOBB University of Economics and Technology, duyguserdaroglu@yahoo.com
} 
the influence of the socio-cultural realities and discourse of the time, meaning it is open to changes and revisions and multiple readings. In that way, New Historicism deconstructs and reconstructs the truth-ness of history as well as its universal and traditional representation.

Since New Historicist approach problematizes the relationship between history and truth, this article will be dwelling on the problematic representation of history(ies) as a grand narrative with a critical eye on memory, document and narrative technique, which will be analyzed in Kazuo Ishiguro's When We Were Orphans as an important constituent of (re)narrating history(ies). The purpose of this article is to offer an alternative interpretation to Kazuo Ishiguro's work When We Were Orphans by analyzing the representation of (public and private) history from the New Historicist viewpoint by focusing on the concepts of time, memory and narrative technique, hence to reveal the unreliability of history as an objective and universal grand narrative by showing how history is narrated in subjective multiple ways and how personal histories and public histories are intermingled in the work.

When We Were Orphans is a story of a detective named Christopher Banks who is in search for his lost family. Born in Shanghai's International settlement", Christopher lives here till the time when his father and his mother suddenly disappear. Later, some arrangements are made by an uncle of Banks and as a result, Banks is sent to England to live with an aunt. Banks grows up there and he becomes a detective mostly with the desire to find his family. Meanwhile, he adopts an orphan, like himself, named Jennifer and he also has a relationship with a woman called Sarah Hemmings. In his thirties, Banks decides to go back to Shanghai to find his parents with the patches of his childhood memories and he finds himself in the midst of the Second Sino-Japanese war. Regardless of the difficulties he encounters in Shanghai because of the war, he eventually finds his childhood friend Akira, then his so called uncle and finally a woman he thinks to be his mother and all the "truth" and "history" of his family and his life is revealed and the novel ends with a sixty-year old Christopher Banks telling his life story by looking back to his life/childhood and his search in Shanghai. In short, the novel is about a detective whose ultimate goal is to find the mystery about his family, thus himself and to fill the gaps in his past by uncovering the secrets with his childhood memories, which also shapes and reshapes his present.

\section{Shifting Time}

When the novel is analyzed from the perspective of New Historicism, it is easily seen that the protagonist of the novel tries to interpret his past with his present mind in a very subjective and unreliable way as he is talking about private history. In the end, he is in search of his past with his present mind and childhood memories. Although at the center of New Historicism there is history, New Historicism claims that the past is interpreted with the present mind and as a result of this there cannot be universal or objective histories but subjective and private histories. Greenblatt who has formulated New Historicism as a doctrine (1990) highlights this in Learning to Curse: Essays in Early Modern Culture as;

[New Historicism] does not posit historical processes as unalterable and inexorable, but it does tend to discover limits or constraints upon individual intervention. Actions that appear to be single are disclosed as multiple; the apparently isolated power of the individual genius turns out to be bound up with collective, social energy (Greenblatt, p. 221).

Greenblatt here focuses on the multiple histories which are open to interpretations, in other words, he rejects the objective and universal representation of history as a grand-narrative. Time shifts in the novel are good evidence for this because the divergence between the real time and the time in the protagonist's/narrator's mind, which is also the imagined time, is the main

\footnotetext{
*Starting from 1863, Shanghai consisted of three parts: The International settlement; the French concession; and the area under Chinese jurisdiction" (Ristaino, 1987, p. 9).
} 
focus of the novel. There is shifting time in the novel from the very beginning to the very end which makes time very indefinite as well as unreliable. The historical time given in the novel is interfered and misinterpreted by the private time/history of the protagonist, so, depicted time becomes unreliable and confusing for the readers. Thus, what is remembered and what is imagined become ambiguous. Especially after Banks goes to Shangai, the real time and the imagined/remembered time become so intermingled that it becomes very difficult to distinguish what is present and what is past, real and imagined and remembered as well as presence and absence. Hence, from the very beginning to the very end of the novel, the narrator disturbs the readers by making them confused about the time and place as he is moving between past and present as well as reality and imagination. As Tim Christensen (2008) asserts, the story in the novel is not "related in linear chronological order but loosely structured around reiterative confrontation with certain unreliable memories" (Christensen, 2008, p. 210). As the narrator is telling the story from the future about the past and present, there are shifts in time and place. However, there are also shifts in what the narrator tells, that is to say, when the narrator talks about the time of the events, in each part (of the novel); the story begins with a different time. In part one, for instance, although the writer says that the date is July 24, 1930 London, the narrator's story begins as "It was the summer of 1923", thus, there is a gap of seven years in between (Orphans, 3). In part two, the writer gives the time as "Part Two: London, 15th May 1931," however, the narrator starts telling the story when he and his childhood friend Akira were six years old, so actually he is talking about a childhood memory. Hence, the readers get perplexed about the time and they travel between the past and the present like Christopher Banks himself.

The shifts between the present and past events of the story also cover the gaps in the narrator's memory and the readers, as a result, witness his struggle to remember what has already been forgotten and/or to forget what has already been remembered. The narrator is stuck in his childhood and its memories in time as well as in place, and he is not sure about what he remembers and what he has forgotten. Hence, the line between the present and past becomes distorted not only for the narrator but for the readers, which makes it difficult to follow the narration and the narrator. When the novel ends, it is also seen that the 60 -year old Christopher Banks is telling the story of the 30-year old Christopher Banks, who is trying to find his parents by remembering the 9-year old Christopher Banks. Therefore, for Christopher Banks, what is past and what is present and what is real and what is imagined as well as what is remembered and what is forgotten are all intermingled. One of the most crucial memories, for instance, is about the disappearance of his father and it becomes a recurring theme for the games he and his childhood friend's Akira played when they were little since they spent a lot of time together with these games especially after this incident. Being told a story about his parents' disappearance, in the games they play, Banks believed that his father was a captive "in a house somewhere beyond the Settlement boundaries" and it was Banks' main goal to find this house and to rescue his parents. Not surprisingly, later, it becomes the only thing he remembers well when he goes back to Shanghai in his thirties to find his family without knowing if what he remembers is one of these games they used to play with Akira (Orphans, 131). Banks, himself, also admits that when he was a child, together with Akira, they tried to find out new games to spend time, and that is why they created "endless variations" of his father's story (Orphans, 131). Years later, when he goes back, the reason why he is unable to differentiate if they are just games or the realities of his childhood is his desire to find his family. The first thing when he goes back to Shanghai is to find the house where he thinks his parents are captives in the Settlement and he spends days to find that house to rescue his parents.

The unreliability of Christopher Banks' memories about the games he and his childhood friend used to play is also noticeable as they were also changing some parts of the play that he 
did not like, especially the parts about his parents' being captives. That is, the game of his parents' disappearance changed every time they played according to Banks' wishes. Banks tells his memories about this;

[...] Akira gestured to me-indicating that I should play with him- and said' You tied up in chair.' We had been in full flow but now I stopped. 'No,' I said. 'My father isn't tied up. How can he be tied up all the time?'

Akira, who never liked to be contradicted when unfolding a narrative, repeated impatiently that my father was tied up in a chair and I should mimic this at the foot of a tree without further delay. I shouted back: 'No!' and stalked off. [...] After a moment I heard Akira's footsteps behind me and raced myself for a full-blown argument. But to my surprise, when I turned to him, I saw my friend gazing at me with a conciliatory look. He came closer and said gently: 'You right. Father not tied up. He very comfortable. Kidnappers' house comfortable. Very comfortable. (Orphans, 131)

Christopher's spending these long years with these memories is the only link between him and Shanghai and thus his childhood. Because of this reason, when he gets lost in the middle of the Sino-Japanese War, his correspondence with the only person he remembers from his childhood Akira (or the soldier whom he thinks is Akira) makes him so confident that he becomes more sure that he remembers the events correctly and now that he has found Akira, like the games they used the play, they can find his parents and they can end the game happily. He conveys this hopeful moment as,

It was as though I had disturbed some dark ritual, and my first inclination was to walk on past. Perhaps it was because I heard a noise, or perhaps it was some sixth sense [...] I then saw in the dim red glow the figure of a Japanese soldier lying quite still on his side. [...] His face and hair were covered with dust and speckled with blood. For all that, I recognized Akira with no difficulty (Orphans, 293).

Banks, at that moment on the border between the present and past is ready to believe that the Japanese soldier he sees on the way to find the house in the middle of Sino-Japanese war is Akira. Although he is not certain that the soldier is Akira, he never questions this since he needs to believe that he is Akira so that he can be strong enough to continue. On the other hand, the wounded soldier who Christopher thinks is Akira may not be Akira as the soldier's answers are given to protect himself in this dangerous situation. In spite of his insisting on making the soldier recognize himself, the Japanese soldier shows no indication of knowing Christopher. However, Christopher never gives up till he hears what he wants to hear;

'Christopher' he said, almost experimentally. 'Christopher.'

'Yes, it's me. Really. It's been a long time. And not a moment too soon, it would seem.'

'Christopher. My friend' (Orphans, 296).

Even though the Japanese soldier says Christopher's name, the readers can never be sure about this fact and they have to believe in what Banks tells them. Christopher Banks' shifting between present and past affects the reliability of what he narrates since he is visiting his past with his childhood memories which are shaped and reshaped in his every remembering; however, there is the distance of thirty years between his memories and the present. Since he cannot realize this, he comes and goes between real time and time in his mind and in that way is unable to find out the mystery about his life and parents.

\section{Unreliability of Memory}

The unreliability of memory which is another principle tenet of the New Historicist approach is seen in the novel as the relationship between truth and memory. The reliability of the memories, especially, the narrator's/protagonist's memories and the question "whose truth is it?" are crucial in the novel. That is to say, New Historicism focuses on multiple truths and in the novel it is obvious that there are multiple truths and the protagonist is coming across a 
different truth while he is searching for the mystery in his life. Very similar to the unreliable time in the novel, memories and multiple truths are also unreliable and confusing for the readers. Christopher Banks, believes in his truth and he is in search of his truth after 30 years and because of this reason his memories become much more important than the public history or the documents and hence, as he remembers and forgets and as he distorts and misinterprets the memories in accordance with his wishes, his memories as well as the public/private history become unreliable, variable and perplexing for the readers.

According to Frederic Jameson (1993), the memories which idealize the past and thus create a different past in the mind of the rememberer as something better than present is due to the repressed feelings and thoughts and as a result of the distance to the past and the struggle to reshape the past as well as the present (Jameson, 1993, p. 18). Christopher Banks remembers the past events, reshaped in every remembrance since his childhood, which is as Jameson states "simulacra" for it is a reformulated version of past as well as a motivation for him to exist in his present. It takes Christopher Banks thirty years to accept and to start the search by combining the bits of his childhood memories and he created an ideal image of Shanghai with a picture totally different from the real one and he sees it when he goes back. Banks reveals his feelings about this search for the truth in his imagined past in Shanghai in his memories as;

For the truth is, over this past year, I have become increasingly preoccupied with my memories, a preoccupation encouraged by the discovery that these memories-of my childhood, of my parents-have lately begun to blur. A number of times recently I have found myself struggling to recall something that only two or three years ago I believed was ingrained in my mind forever [...] to take, for instance, this episode I have just recounted concerning my mother and the health inspector: I am fairly sure I have remembered its essence accurately enough, turning it over in my mind again, I find myself less certain about some of the details (Orphans, 80-81).

As it becomes more difficult for Banks to remember and he cannot be sure about the truth-ness of the details in his memories, he gets more stuck in his memories and the line between what is real and what is imagined becomes more indistinguishable. After some time he begins to believe in what he imagines and the memories become more unreliable as he talks about the details of the past as a result of his remembrance and re-remembrance.

In the interview with Gregory Mason (1989), Ishiguro states that "[t]hings like memory, how one uses memory for one's own purposes, one's own ends, those things interest me more deeply" (Mason, 1989, p. 347). This summarizes how Ishiguro's protagonist, Christopher Banks, uses the patches of his childhood memories for his own sake and purpose to find his identity and to exist in his present in every version of remembrance.

Banks' remembering the same story in a different way in each time is closely related with Greenblatt's definition of "resonance." According to Greenblatt, "resonance" is a sound's quality of being deep, clear and echoing (Greenblatt, 1996, p. 228). He also focuses on the resonant effect of "verbal, aural and visual traces to produce, shape and organize collective physical and mental experiences" (Greenblatt, 1990, p. 6). Accordingly, in Banks' every remembrance of the past, his memories are echoed, repeated and deepened and as a result of this, Banks reshapes his memories consciously and unconsciously. Thus, history is (re)textualized and historicized in every remembrance. The effect of it is closely related to the reader and the work, the relationship between present and past as well as textuality and historicity. Thus, New Historicism aims to study the relationship between historical and cultural meanings of the text as a result of remembering and forgetting of past and present. Because of this reason, what is remembered and what is forgotten is of utmost significance as well as the distance with the past since there are alterations in every remembrance of the same event. Like Banks, the rememberer may not be aware of reshaping of the past in every remembrance/forgetting, but shapes his past and present according to his memory. Thus the 
textuality and historicity of past and present, and the position of the reader to awaken the readers' cultural wonder at the resonance is not only in present but also in past.

Greenblatt, in Learning to Curse, also argues that the happenings from the past show an "otherness," which can renovate personal experience and understanding (Greenblatt, 1990, p. 14). In other words, as there is no access to the past, the past is in the hands of the rememberer to be reformulated and bettered and thus, the past becomes otherized by the rememberer in every narration or reminiscence. When Christopher Banks sees the house and the person whom he thinks is his friend Akira, he re-remembers his childhood in a more detailed way and seeing all these after long years makes him believe in his memory. However, the more he finds out about the past, his truth becomes more painful for he comes across a different truth. When Banks is more curious about the past and the/his truth of his life/parents and as he reveals it, the past becomes more "de-familiarized" and "re-fashioned" for him, which makes him mystified and disappointed. What he has to confront with is the clash between his truth and the given truth by his so-called aunt and Uncle Philip since they are completely different from each other.

\section{Public/Private Histories}

The novel is a multi-layered novel (historical, psychological, personal and autobiographical) in which public history is intersected and transformed by personal history, which is the focal point for New Historicism. In When We Were Orphans personal history and public history are combined; that is, the historical background, the Second Sino-Japanese War is combined with Christopher Banks' personal and fantasized history. He explains the reason for his using public history as, "what I started to do was to use history [...] I would look for moments in history that would best serve my purposes or what I wanted to write about" (Ishiguro, 1991, p. 115). In this way, he "denaturalizes" the realities and facts of the historical background by combining it with the fictionalized, fantasized and idealized personal history. Hence, the protagonist's memories become more significant than both the documents and the public history. Namely, public history is reshaped by private history of the protagonist to modify his/her personal history.

As Linda Hutcheon (1989) says, "the past is not an 'it' in the sense of an objectified entity that may either be neutrally represented in and for itself or projectively reprocessed in terms of our own narrowly 'present' interests" (Hutcheon, 1989, p. 57). Hutcheon indicates that past cannot be narrated and dealt with an objective way, but in a subjective way due to the narrator's present viewpoint. Another important name of New Historicism, Louis Montrose also talks about the blurry line between history and text/fiction, thus subjectivity of history as "the historicity of texts and the textuality of history." He (1989) explains what he means by "historicity of the texts" and "the textuality of history;"

[b]y the textuality of history, I mean to suggest firstly, that we can have no access to a full and authentic past, a lived material existence, unmediated by the surviving textual traces of the society in questiontraces whose survival we cannot assume to be merely contingent but must rather presume to be at least partially consequent upon complex and subtle social processes of preservation and effacement. Secondly, that those textual traces are themselves subject to subsequent textual mediations when they are construed as the "documents" upon which historians ground their own text, called "histories" (Montrose, 1989, p. 20).

As indicated by him, history cannot be a passage to an authentic past without traces of complex social processes of handling these texts and documents which are not untouched by those who pen them. According to Montrose, the meaning of a text is not stable, even when it is historically specific and in every reading of the very same text, there can be various meanings. Hence, Montrose believes that there are histories of historians; there is not one history which is the same for everyone and for every period but there are subjective and private histories (Montrose, 1989, p.20). 
Similarly, Banks by recreating the past depending on his childhood memories reasserts the denaturalization and thus, the subjectivity of history. Hutcheon (1989) highlights the unclear outlines of the relationship between history and fiction, which is also the relationship between public reality and personal history as one affects the other, "[B]oth history and fiction are discourses; human constructs, signifying systems and both derive their major claim to truth from that identity" (Hutcheon, 1989, p. 93). Hence, Ishiguro uses the public history for his own depiction of his characters in the novel, and he places the personal history of Christopher Banks in the public reality/history. In this way, it is not clear for readers if Ishiguro also fictionalizes the public reality just like his protagonist's fictionalized history. The Sino-Japanese war as well as the situation of Shanghai is also depicted from a fictionalized/imaginary person's point of view. This is also significant for the depiction of history as Ishiguro allows his protagonist to portray his personal history from an intermingled point of view, that is to say, both as a detective and as a person with childhood memories. Accordingly, the depiction of history in the novel becomes twofold; both private (the personal history/Banks' search for his parents) and public (the public reality/Sino-Japanese War). Ishiguro is exploring Banks' past/private history as a detective fiction writer by using the dynamics of the genre and parodying them, but at the same time he is telling Banks' personal history as well as public history like a historian/novelist. Banks becomes a historian/detective who is in search of his parents in a broad public history of Britain when the opium trade is considered and Japan when the Asia-Pacific war is considered. Thus private history is given within the public history and they are intermingled. However, that fictionalized world with the fictionalized detective in the novel constructed a textualized version of Chinese (public) history. This new kind of historical (detective) fiction shows, as stated by Janik (1989);

the validity, necessity and difficulty of acknowledging, confronting and dealing with the past, both private and public as defined by Fleishman: a concern with the past beyond the present and previous generation, an inclusion of public events that affect the lives of fictitional characters, and an emphasis on universal meanings that might be derived from historical contexts rather than on the analysis of public facts (Janik, 1989, p. 162).

Ishiguro creates a ground on which he can clearly depict the effects of the public history on individuals' lives through his fictional characters and this is also the reason of the shifts between present and past as Finney (2006) points out as "the past is alive in the present" (Finney, 2006, p. 148). What people remember and tell is more important than what really happened in the past for Ishiguro. That is why, he believes that the present understanding and re-remembrance of the past are more important. Although the personal history and the public history are interconnected in the novel, what matters for the readers as well as the writer himself is Banks' his-story and truth he is searching for in the middle of the actual public history of Sino-Japanese war, which covers the last parts of the novel when Christopher Banks is trying to find the house where his parents are captivated. Accordingly, Ishiguro depicts the struggle of his protagonist who tries to survive with/in the memories in the midst of public history and personal history. Although Banks shows the tension between memory and history, he also depicts the intermingled effect of history and memory. In other words, personal history is affected by public history and in return, public history is affected and reshaped by the personal history. This is what Louise Montrose underlines in his "Professing the Renaissance," as "our analyses and our understandings necessarily proceed from our own historically, socially and institutionally shaped vantage points; that the histories we reconstruct are the textual constructs of critics who are, ourselves, historical subjects"(Montrose, 1989, p. 23). To Montrose, the past is always conducted by the present consciousnesses and it is inevitable to make a distinction between various histories (private, public and local histories) and they are already intermingled with each other. By pointing out the historical side of the text by "historicity of texts" and literary side by "textuality of history," Montrose highlights the relationship of the text and 
context and by mentioning about multiple histories, he asserts that there are not any boundaries between text(uality) and context(uality). In short, Montrose underlines multiple interpretations instead of one unique understanding of history.

Similarly, in the novel, Christopher Banks reshapes his personal history with public history. Hence, in the novel, there is a fine line between public history and personal history as well as memory and history. However, in When We Were Orphans, the readers also see the clash between private memory of Banks and his personal history, which helps Banks to reconstruct his identity since what he has believed for thirty years does not match with what he is told. In this way, Ishiguro depicts a different perspective of public history by making his character reshape it with his memories. Actually, what Ishiguro's protagonists Christopher Banks uncovers in public history while searching for personal history/truth is not the objective public history of that time, the opium trade in Japan or Sino-Japanese War, but how he, himself, and his truth are affected and shaped and reshaped during and after that period. In the novel, in the middle of the war, Christopher Banks' struggle to find the house in which his parents have been captivated for years is ironical and within the public history he is trying to find his personal history and truth. The 30-year of difference both in time and space does not prevent Banks from finding his identity/existence clung to the public history of Japan. For this reason, he is trying to frame his presence within his past which is very similar to his trying to live in past within his present.

Christopher Banks' attachment to his memories is what makes him detached from the truth for which he is in search for years. When he realizes that there is a great difference between the truth he believes in his memories and the truth in reality, he gets disappointed and he finds himself in the beginning of his search. In that sense, it is understood that what Banks is looking for is not the truth but the truth as it exists in his memories. That is to say, when he is sent to England to live with a so-called aunt whom he has never seen in his life, he is told a story and for years till he meets his so-called uncle, he believes in that story. Believing in the narrated story before he leaves Shanghai, Banks tries to construct a whole picture with these memories and he finds himself facing the narrated past in Shanghai. Having been away for long years out of Shanghai, Banks creates a different Shanghai, a frozen picture shaped by his childhood memories and when he faces the reality, he is disenchanted with history, both personal and public. Banks' disillusionment deepens when he faces his so-called Uncle Philip whom he barely recognizes when he sees him. Uncle Philip in Banks' mind and the real Uncle Philip are totally different from each other. However, what is more disappointing for Banks is what this so-called Uncle Philip tells about his parents, he tells a very different story about Banks' parents than the truth that has reshaped Banks' personal history as well as his life/existence. When they meet, Uncle Philip asks

'Tell me, Christopher. What do you believe happened to your father?' knowing that Banks believes in a different story.

'Is it any business of yours what I believe? I came here to hear it from you.'

'Very well. But I was curious to know what you'd worked out for yourself. After all, you've made quite a name for yourself for such things' (Orphans, 336).

As a result of his anger and detestation and longing for the truth of his life and thus the meaningfulness of his existence, he shares the story he believed in for these years. However, Uncle Philip tells a different story about Christopher Banks' parents, which shatters the picture that Banks has had since his childhood. That picture is not the picture that he wants to see as Uncle Philip tells that

Your father ran off one day with his mistress. He lived with her in Hong Kong for a year, a woman called Elizabeth Cornwallis. But Hong Kong is awfully stuffy and British, you know. They were a scandal, and in the end they had to rush off to Malacca or some such place. Then he got typhoid and 
died in Singapore. That was two years after he left you. I'm sorry, old fellow, it's hard to hear all this, I know (Orphans, 336).

His so-called Uncle Philip also reveals that Banks' mother knows his father's story as a result of a letter written by his father telling the truth. After hearing that his father ran off with his mistress, unbelievingly, Banks first asks if any detectives were hired and if they found any evidence or solved the mystery. This is a critical and meaningful question due to Banks' being a very famous detective and for him nothing can remain uncovered by a detective (one like him) and he cannot believe that his father cannot be found anywhere (Orphans, 337). However, it is him again, the successful detective who solves all the mysteries for other people, but who is unable to solve his own mystery. While Banks is busy with the heaviness of his failure, he becomes more uncomfortable with what Uncle Philip says about the detectives,

The detectives? Those underpaid, overworked flat-feet? They wouldn't have found an elephant gone missing in Nanking Road. [...] She [Banks' mother] would have told you eventually. But we wanted to protect you. That's why we had you believe what you did (Orphans, 337) (italics added).

It is clear that Banks is disturbed not only because of the truth that Uncle Philip is telling, but because of the inability of the detectives in finding his father. The insulting words that Uncle Philip uses for the detectives also make him more restless. Like these unsuccessful detectives, he, himself, could not find his father, either. Later, the question that Uncle Philip asks is also a significant clue about the things he is going to tell, "How much do you know already about her [his mother]?" (Orphans, 338). Yet, Banks is unable to gather the clues and find the truth he has been looking for years. After being told his mother's story, Banks also learns that his mother is alive and without questioning the truth-ness of this information, he believes in it. However, Banks realizes that all he has known for years as the truth about his parents and himself, was not true. For a life time he had believed in the truth which was created for him, for his sake by his mother for whom he has been searching. Then, this Uncle Philip tells the reason for creating the truth for him as,

Because I want you to know the truth! All these years, you've thought of me as a despicable creature. Perhaps I am, but it's what this world does to you. [...] And look at me now. You despise me. You've despised me all these years, Puffin, the closest thing I ever had to a son, and you despise me still. But now do you see how the world really is? [...] How you were able to become a celebrated detective? A detective! What good is that to anyone? Stolen jewels, aristocrats murdered for their inheritance. [...] Your mother, she wanted you to live in your enchanted world for ever. But it's all impossible. In the end it has to shatter. It's a miracle it survived so long for you (Orphans, 346).

Uncle Philip's confession is not only for Banks but also for himself. Because of his love for Banks' mother and inability to save her, for years he could not express his feelings to anybody but himself, but now, he tells everything to Banks who has lived in a created history/past for years, too. It is also not clear if Uncle Philip is telling the truth or his own truth similar to Banks who has believed in his truth for years. As Stephen Greenblatt (1985) claims in "Invisible Bullets," that "the historical evidence is unreliable, even in the absence of social pressure, people lie readily about their most intimate beliefs. How much more must they have lied in an atmosphere of unembarrassed repression" (Greenblatt, 1985, p. 474). It is likely that Uncle Philip to comfort himself or to justify what he has done for all these years, tells his truth/ his-story to Banks who is already ready to believe in what he is told without questioning anything. Banks needs to be told his past. Owing to this need, Banks goes to find his mother. Banks' going to Hong Kong without checking if the information given by Uncle Philip is true or not, is also ironical because he is a well-known and successful detective, however, Christopher Banks goes and visits his mother in a nursing home. The woman who is said to be his mother and known as Diana Roberts, "had been living in an institution for the mentally ill in Chunking since the end of the war" (Orphans, 354). When Banks sees his mother, she has been staying there for two years and she is unable to remember anything, which is also 
ironical. After 30 years, Banks' mother does not have any hint of remembering Banks. As Banks is trying to make his mother remember himself, his mother does not give a hint of remembrance of anything. Then, Christopher says "It's Puffin" to his mother, the name she used to call her son when he was a boy years ago. Christopher sees the hints of remembrance in his mother's face as she speaks out "'Puffin,' she repeated quietly to herself, and for a moment seemed lost in happiness. Then she shook her head and said: 'That boy. He's such a worry to me" (Orphans, 358). When Christopher has a critical moment with the desire of forgiveness for Puffin for his inability to find her she says, "'Forgive Puffin? Did you say forgive Puffin? Whatever for? [...] That boy. They say he's doing well. But you can never be sure with that one. Oh, he's such a worry to me. You've no idea'" (Orphans, 358-59).

When Christopher Banks is telling this event to Jennifer, his daughter, later, he seems to be relieved for having found his parents and the truth of his past. He can never be sure if that woman was his mother; neither is he sure of the Japanese soldier was his friend Akira. In his journey to his past, it is not clear if his memories lead him to find the formulated truth in his formulated past or if he leads the past by remembering and forgetting what he wants and reshaping his memories as well as the truth he wants to believe in.

At the end of the novel, the historical setting gains more importance in terms of private and public histories. As mentioned before, there are two significant historical settings in the novel; the novel starts with the Sino-Japanese War in colonial period, which represents the past in the novel. The novel ends in the post-colonization period after China won its freedom, which represents the present in the novel. However, very similar to the conflict in real time and the imagined time, past and present, now and then, here and there, the historical settings are also intermingled for Banks and he is looking from his memory disregarding all the documents, evidence, places and time for his personal history often imagined truths.

\section{Conclusion}

It is conclusive that New Historicists claim that it is almost impossible to talk about history as a grand-narrative and one absolute truth that is true for everyone. Yet, this does not mean that New Historicism denies the idea of grand-narrative, but it denies the totalisation and objectivity of grand-narratives, and for the New Historicists, every piece of work can be a grand-narrative. New Historicism also underlines the indistinct line between private and public histories and points out the idea that public history can be inscribed in the private histories of people and private histories can (re)shape public histories told. Thus, the clash between the public and private histories proves the various subjective representations of multiple histories by depending on memory and concept of time.

To conclude, the novel clearly reflects the problematic nature of representation(s) of history by challenging the grand-ness of history by giving multiple versions of the past events depending on the narrator's perspective and understanding of the past, and thus to highlight the fact that history is a human construct as can be clearly seen through the protagonist's private history which is also interrelated with public history. The same past event can be narrated in various ways depending on the narrators' viewpoints and understanding of the events, which questions the understanding of history as a grand-narrative. Christopher Banks' history is formulated and reformulated by his memories and when he encounters a different version of history, what he has believed for thirty years is deconstructed and reconstructed. In the end, in spite of what he has been told to him about his past, Christopher Banks has not solved the mystery of his life as well as his parents because of his attachment to his memories, which are to him the only documents about his past. 


\section{Works Cited}

Adanur Doğan, Evrim (2006). "New Historicism and Renaissance Culture," Ankara Üniversitesi Dil ve Tarih-Coğrafya Dergisi, Sayı 45/1.

Christensen, Tim (2008). "Kazuo Ishiguro and the Orphanhood" 6 February 2015.

Web. http://seas3.elte.hu/anachronist/2008Christensen.pdf

Finney, Brian (2006). English Fiction since 1984: Narrating a Nation. New York: Palgrave Macmillian.

Greenblatt, Stephen (1985). "Invisible Bullets: Renaissance Authority and Its Subversion." Political Shakespeare: New Essays in Cultural Materialism. Ed. Jonathan Dollimore, Alan Sinfield, and Raymond Williams. Manchester: Manchester UP. 18-47.

Greenblatt, Stephen (1990). Learning to Curse: Essays in Early Modern Culture. London: Routledge.

Greenblatt, Stephen (1996). "Resonance and Wonder." Kiernan Ryan. Ed. New Historicism and Cultural Materialism: A Reader. London: Arnold.

Hutcheon, Linda (1989). The Politics of Postmodernism. New York: Routledge.

Ishiguro, Kazuo (2000). When We Were Orphans. London: Faber \&Faber.

Ishiguro, Kazuo and Oe Kenzaburo (1991), "The Novelist in Today's World: A Conversation", Boundary, 18/3: p.115.

Jameson, Fredric (1993). Postmodernism, or, The Cultural Logic of Late Capitalism. Durham: Duke UP.

Janik, Del Ivan (1989). "History and the 'Here and Now': The Novels of Graham Swift." Twentieth-Century Literature 35: 74-88. 27.08.2014.

Mason, Gregory (1989). "An Interview with Kazuo Ishiguro.” Contemporary Literature 30: 334-47.

Montrose, Louis A. (1989). "Professing the Renaissance: The Poetics and Politics of Culture" The New Historicism. Ed. H. Aram Veeser. New York: Routledge.

Ristaino, Marcia R (1987). China's Art of Revolution: The Mobilization of Discontent, 1927 and 1928. Durham: Duke University Press.

Veeser, H. Aram (1989). The New Historicism. New York: Routledge. 